\title{
Biocontrol of angular leaf spot disease and colonization of cucumber (Cucumis sativus L.) by endophytic bacteria
}

\author{
Mustafa Akbaba ${ }^{*}$ and Hatice Ozaktan
}

\begin{abstract}
Endophytic bacteria (EB) isolated from healthy cucumber plant tissues (e.g., root, stem, leaves) were evaluated as possible biological control of Pseudomonas syringae pv. lachrymans, the causative agent of angular leaf spot disease in cucumber. In this study, 24 endophytic bacteria were selected for tests based on biocontrol traits such as indole-3-acetic acid and siderophore production, solubilization of phosphate, and inhibition growth of $P$. syringae pv. lachrymans in vitro. Some of the selected endophytes successfully inhibited the pathogen were tested in pots. In the pot experiment, two isolates (CB361-80) and (CC372-83) were selected as the most promising biocontrol agents tested against the pathogen.

According to the identification carried out by using $16 \mathrm{~S}$ rRNA primers and sequence analysis, the two selected endophyte isolates (CB361-80) and (CC372-83) showed 99\% similarity to Ochrobactrum pseudintermedium and Pantoea agglomerans, respectively. Two EB isolates colonized seeds at the rate of $3 \times 10^{6}-7.1 \times 10^{7} \mathrm{CFU} / \mathrm{g} 1$ day after seed bacterization. The population of the two EB isolates in cucumber tissues were found to be about $2 \times 10^{4}-7.5 \times 10^{4} \mathrm{CFU} / \mathrm{g}$ in roots and $3.8 \times$ $10^{4}-2.2 \times 10^{5} \mathrm{CFU} / \mathrm{g}$ in shoots 45 days after seed bacterization. The populations of the two isolates in the root and shoot tissues did not decrease following the inoculation of the pathogenic bacterium. The endophytic strains CB361-80 (Ochrobactrum sp.) and CC372-83 (Pantoea sp.) successfully colonized the cucumber tissues.
\end{abstract}

Keywords: Biological control, Cucumber, Endophytic colonization, Pseudomonas syringae pv. lachrymans, Ochrobactrum pseudintermedium, Pantoea agglomerans

\section{Background}

Cucumber (Cucumis sativus L.) is one of the most widely cultivated vegetable crops worldwide. Turkey is the second largest cucumber producer worldwide after China, with an average production of about $1.754 .613 \mathrm{t}$ per year (Anonymous 2013). Several fungal, viral, and bacterial diseases have adversely affected cucumber production in Turkey; among them is the gram-negative bacterium Pseudomonas syringae pv. lachrymans (Smith \& Bryan) Young, Dye \& Wilkie (Psl), which is the causative agent of angular leaf spot disease (Smith and Bryan 1915). It may cause significant yield losses in both greenhouse and field production (Bhat et al. 2007). Under climatic conditions conducive to its proliferation, the disease caused severe damage and economic loss to farmers of cucumber and other cucurbits in Turkey

\footnotetext{
* Correspondence: mustafa.akbaba@ege.edu.tr

Department of Plant Protection, Faculty of Agriculture, University of Ege, Bornova, 35100 Izmir, Turkey
}

(Ozaktan and Bora 1994). This disease resulted in the loss of cucumber production at the state of Wisconsin (USA). The bacterium overwinters in seeds and on infected plant debris on the surface of the soil. Seedborne bacteria spread to the cotyledons when the seed germinates. The bacterium usually invades cucumber tissues via stomata, hydathodes, lenticels, and scars. The pathogen multiplies in the intercellular spaces of cucumber plant tissues. The symptoms of angular leaf spot disease can appear locally or systemically in cotyledons, leaves, stems, and fruits (Bhat et al. 2010). Angular leaf spot first appears as water-soaked spots (lesions) on the underside of leaves. Small leaf veins restrict these angular lesions associated with a slimy white film that oozes from the lesions under damp conditions. Lesions eventually become visible on the upper leaf surface and appear as irregular reddish-brown spots that may become necrotic. Systemic infections may occur and involve all types of vascular tissue. Rain and wind play 
important roles in disseminating the pathogen (Bhat et al. 2010; Shila et al. 2013). The most effective disease control strategy is the use of pathogen-free seeds. Other important disease control strategies include the use of biological, chemical, cultural, and integrated methods to decrease pathogen populations. Copper compounds applied to plants may reduce secondary inoculum and protect tissues from infection but are only effective on plant surfaces. Therefore, copper cannot control systemic pathogen movement inside cucumber plants (Khlaif and Abu Blan 1990; Bhat et al. 2010). Additionally, the excessive use of copper-based agrochemicals to control plant diseases frequently leads to environmental contamination, chemical residues in foods, harmful effects on non-target organisms, and increasing pathogen resistance (Bhandari 2014). Biological control using antagonistic bacteria was also considered as a way to control Psl-induced disease on cucumber plants (Liu et al. 1995a). In recent years, some researchers have focused on the bioactivities of endophytic microorganisms as producers of a plethora of substances that might play a role in the microbe-microbe or plant-microbe interactions (Strobel and Daisy 2003). Endophytic bacteria used as biocontrol agents and bio-fertilizer have received much attention as an alternative strategy to chemical control (Gerhardson 2002; Compant et al. 2005; Thomas and Upreti 2014). Endophytes locally or systemically colonize internal plant tissues without causing infection or negative effects in host plants. Plant-associated microorganisms like fungi, bacteria, and actinomycetes have been reported as endophytic colonizers in internal plant tissues (Azevedo et al. 2000; Bandara et al. 2006; Johri 2006; Miguel et al. 2013). Endophytic bacteria can be found in the genera Agrobacterium, Arthrobacter, Bacillus, Burkholderia, Chryseobacterium, Enterobacter, Klebsiella, Micrococcus, Ochrobactrum, Paenibacillus, Pantoea, Pseudomonas, Salmonella, Serratia, and Stenotrophomonas. Some of these genera include species that are human or animal pathogens (Rosenblueth and Martínez-Romero 2006; Melnick et al. 2008; Assumpção et al. 2009). Endophytes were also evaluated as sources of novel bioactive metabolites that could be used in medicine, agriculture, and industry. These secondary products vary according to host plant species and location (Bills and Polishoo 1991; Ruby and Raghunath 2011). Non-pathogenic bacteria have been reported to induce systemic resistance against bacterial angular leaf spot disease of cucumber (Liu et al. 1995a; Wei et al. 1996). Seed coating or cotyledon treatment with plantgrowth-promoting rhizobacteria (PGPR) including Bacillus pumilus, Flavimonas oryzihabitans, Serratia marcescens, and Pseudomonas putida induced systemic disease resistance strains in cucumber: the bacterial treatments significantly decreased lesion number and size and pathogen populations on cucumber plants (Liu et al. 1995a; Wei et al. 1996). In other experiments, endophytic Pantoea agglomerans controlled effectively cucumber anthracnose (Colletotrichum orbiculare) (Zhang et al. 1998).

The objective of this research was to investigate the biocontrol activity of 24 endophytic bacteria (EB) isolates against $P s l$ in vivo as well as to assess the internal colonization of cucumber tissues by two EB showing successful biocontrol activity against Psl. Finally, the taxonomic position of the most promising isolates will be determined using the $16 \mathrm{~S}$ ribosomal RNA (rRNA) gene sequence analysis.

\section{Materials and methods}

Plant materials, bacterial isolates, and growth conditions The experiments were conducted in the growth chambers of the Department of Plant Protection at Ege University in Izmir, Turkey, during springtime 2012 and 2013. Seedlings of a cucumber variety (Cucumis sativus "Gordion F1") known to be susceptible to $P s l$ in Turkey were used. Cucumber seeds were sown to a depth of approximately $1 \mathrm{~cm}$ in $10 \mathrm{~cm}^{2} / 500 \mathrm{~cm}^{3}$ plastic pots (one seed per pot) filled with sterile peat. Seedlings were raised in a standard growth chamber at $25{ }^{\circ} \mathrm{C}$ by day, $22{ }^{\circ} \mathrm{C}$ by night, and 16 -h illumination. Seedlings were regularly watered with tap water regularly for 45 days. The highly aggressive strain CFPB 2262 of P. syringae pv. lachrymans, the causative agent of angular leaf spot (ALS) on cucumber, was obtained from the "Collection Française des Bactéries Phytopathogènes" (CFBP, Angers, France) and used as the challenging pathogen in this study. This strain was previously assayed to confirm its pathogenicity on the leaves of the susceptible cucumber variety Gordion F1. In a previous study, 104 EB isolates were isolated from the internal leaf, root, and stem tissues of healthy cucumbers collected from greenhouses and fields in the Aegean Region of Turkey (Ozaktan et al. 2013). The previous in vitro results evaluation of all of these 104 EB isolates used modified "weighted-rankit" method which is use to evaluate many bacterial traits with different weights for a large number of genotypes (Serçe and Görgülü 2009). The weightedrankit method allows for the numerical classification of bacterial strains. Each trait is weighted according to its relative importance and integrated with other weighted characteristics. The data were subjected to variance analysis, which then permits a final quantitative comparison among all the items within the test (Michelson et al. 1958). This method was modified to evaluate many biocontrol and plant growth promotion parameters (i.e., production of siderophore, indole 3-acetic acid (IAA), $\mathrm{HCN}$; solubilization of phosphate; and antibiosis of pathogen) with different weights for a large number of 
bacteria. In this study, 24 isolates characterized previously in vitro tests present in Table 1 were selected to test against $P s l$ in this experiment based on weightedrankit averages. Both the pathogenic bacterium and the endophytic bacterial isolates were maintained on $-80{ }^{\circ} \mathrm{C}$ in liquid NB (Nutrient Broth) amended with 20\% glycerol for long-term storage.

\section{In vivo screening of endophytic bacteria against Pseudomonas syringae pv. lachrymans}

In vivo tests were carried out on plantlets emerging from seeds. The 24 selected endophytic isolates were tested in vivo for their biocontrol against Psl on cucumber plants $\left(25{ }^{\circ} \mathrm{C}\right.$ day, $22{ }^{\circ} \mathrm{C}$ night, 16 -h illumination, 45 days). EB isolates were inoculated twice: once before sowing, as seed coating, and again after transplanting, as soil drench.

Both EB and pathogen were grown on King's B (KB) medium at $24{ }^{\circ} \mathrm{C}$ for $24-48 \mathrm{~h}$ (Schaad et al. 2001). The growing EB colonies were suspended in carboxymethyl cellulose (CMC, $1 \% v / v)$ for the first EB treatment, i.e., seed bacterization. The suspensions were adjusted to an $\mathrm{OD}_{600}$ of 0.1 using a spectrophotometer (PG Instruments T60 UV/VIS). The seeds were rinsed three times with sterile distilled water after being surface sterilized with $1 \%$ sodium hypochlorite for $1 \mathrm{~min}$ and soaked for $30 \mathrm{~min}$ in $\mathrm{EB}$ suspensions amended with CMC. In the control treatment, the seeds were covered with $\mathrm{CMC}$ alone. The seeds were left on blotting papers in a sterile cabinet for $24 \mathrm{~h}$ before sowing. After bacterization, the seeds were sown individually in separate plastic pots filled with sterile peat and maintained under standard growth chamber conditions. The second EB treatment (soil drench) was carried out at the true leaf stage. The suspensions $\left(\mathrm{OD}_{600}, 0.1\right)$ for the second $\mathrm{EB}$ treatment were prepared by growing colonies on $\mathrm{KB}$ medium at $24{ }^{\circ} \mathrm{C}$ for $24-48 \mathrm{~h}$. They were suspended in sterile distilled water. The plants were treated with the

Table 1 Overview of in vitro biocontrol and plant-beneficial traits of selected endophytic bacteria and later used in our study

\begin{tabular}{|c|c|c|c|c|c|c|c|c|}
\hline Isolate codes & Gram stain & $\begin{array}{l}\text { Fluorescent pigment } \\
\text { production }\end{array}$ & $\mathrm{HCN}^{\mathrm{a}}$ & $\mid A A^{b}(\mu \mathrm{g} / m L)$ & $\begin{array}{l}\text { Siderophore } \\
\text { production }(\mathrm{mm})\end{array}$ & $\begin{array}{l}P_{S}{ }^{k} \text { inhibition } \\
\text { zone }(\mathrm{mm})\end{array}$ & $\begin{array}{l}\text { Phosphate } \\
\text { solubilization }(\mathrm{mm})\end{array}$ & Vigor index ${ }^{\mathrm{d}}$ \\
\hline CB23-6 & - & - & - & 44.00 & 10.50 & 0.00 & 0.00 & 2188 \\
\hline CC72-14 & - & - & - & 30.00 & 5.00 & 3.25 & 2.50 & 4386 \\
\hline CB82-16 & + & - & - & 32.00 & 10.00 & 0.00 & 0.00 & 4618 \\
\hline CB93-19 & - & - & - & 33.00 & 12.00 & 6.25 & 0.00 & 4663 \\
\hline CB182-37 & - & - & - & 7.00 & 7.00 & 0.00 & 1.00 & 5089 \\
\hline CC252-49 & - & + & - & 34.00 & 9.00 & 0.00 & 1.00 & 5018 \\
\hline CC26-50 & - & - & - & 16.00 & 0.00 & 0.00 & 0.00 & 4440 \\
\hline CA281-56 & - & - & - & 13.00 & 12.00 & 0.00 & 0.00 & 4453 \\
\hline CA282-57 & - & - & - & 35.00 & 6.00 & 1.00 & 0.00 & 4815 \\
\hline CA291-60 & - & + & - & 25.00 & 3.00 & 2.00 & 2.00 & 4860 \\
\hline CA292-61 & - & + & - & 14.00 & 16.00 & 3.75 & 0.00 & 5312 \\
\hline CC293-66 & + & - & - & 12.00 & 0.00 & 0.00 & 0.00 & 3856 \\
\hline CC30-68 & - & + & - & 24.00 & 16.00 & 3.75 & 2.00 & 5001 \\
\hline CA332-73 & - & + & - & 14.00 & 6.00 & 3.20 & 3.00 & 1546 \\
\hline CB361-80 & - & - & - & 125.00 & 7.00 & 0.00 & 4.00 & 4031 \\
\hline CB362-81 & - & - & - & 20.00 & 10.00 & 0.00 & 0.00 & 4931 \\
\hline CC372-83 & - & - & - & 45.00 & 7.00 & 0.00 & 6.00 & 5390 \\
\hline CA38-85 & + & - & - & 5.00 & 6.00 & 1.00 & 0.00 & 4900 \\
\hline CB382-87 & - & - & - & 50.00 & 6.00 & 0.00 & 1.00 & 5542 \\
\hline CA391-88 & - & - & - & 12.00 & 12.00 & 0.00 & 0.00 & 4696 \\
\hline CC393-93 & + & - & - & 39.00 & 1.00 & 0.00 & 0.00 & 4843 \\
\hline CB401-95 & - & + & - & 11.00 & 11.00 & 0.00 & 3.00 & 4906 \\
\hline CA411-99 & + & - & - & 6.00 & 1.00 & 4.00 & 0.00 & 3249 \\
\hline CC44-112 & - & + & - & 8.00 & 6.00 & 2.00 & 1.50 & 3411 \\
\hline
\end{tabular}

${ }^{\mathrm{a}}$ Hydrogen cyanide production

${ }^{b}$ IAA level after growth in medium supplemented with/without tryptophan

'The values show inhibition of Ps/ development compared to non-treated Psl positive control plates

${ }^{d}$ Mean vigor index value of non-treated negative control was 4947 
suspensions in the form of a soil drench $(20 \mathrm{~mL} /$ plant $)$ at the first true leaf stage 1-2 days before pathogen inoculation (Lwin and Ranamukhaarachchi 2006). Control plants only received distilled water.

The inoculum was prepared from $P s l$ colonies grown on $\mathrm{KB}$ medium at $28{ }^{\circ} \mathrm{C}$ for $24 \mathrm{~h}$. They were suspended in sterile distilled water and the concentration was adjusted to approx. $10^{7} \mathrm{CFU} / \mathrm{mL}\left(\mathrm{OD}_{600}, 0.05\right)$ using a spectrophotometer (Klement et al. 1990). A single drop of Tween 20 was added to each liter of inoculum to ensure effective distribution of the pathogen on the leaves. Cucumber seedlings at the second true leaf stage were inoculated by spraying $P s l$ suspensions on the underside of each true leaves 1-2 days after soil drenching. After inoculation, the seedlings were incubated at $24{ }^{\circ} \mathrm{C}$ for $2-$ 3 days at $95-100 \%$ relative humidity (RH). The seedlings were then placed in a transparent cabinet to maintain high RH (95-100\%) post-inoculation. The cucumber plants were kept in the growth chamber for 14 days after inoculation to monitor disease symptoms. Cucumber plants obtained from non-bacterized seeds and inoculated with the pathogen were used as positive controls. Cucumber plants that had received neither EB nor pathogen were evaluated as negative controls (Fig. 1d).

The experiments were arranged in a completely randomized block design consisting of 10 replicates (one plant per replicate). The experiments were repeated twice under similar conditions. Disease development was monitored for 14 days after Psl inoculation. Disease severity was assessed after 14 days using a visual rating scale from 0 to 4 in which $0=$ no symptoms, $1=$ necrotic lesions covering $<25 \%$ of the leaf surface, $2=$ necrotic lesions covering $25-50 \%$ of the leaf surface, $3=$ necrotic lesions covering $50-75 \%$ of the leaf surface, and $4=$ necrotic lesions covering $>75 \%$ of the leaf surface and plant death (Raupach and Kloepper 2000). The disease index (DI) was calculated by using the formula adapted from Liu et al. (1995b): DI $=[\Sigma$ (Number of plants in the rating $\times$ Rating number)/(total number of plants $\times$ the highest rating)] $\times 100 \%$.

\section{Monitoring endophytic bacteria and pathogen colonization}

Taking into account the results obtained from the in vitro and in vivo experiments and the availability of suitable plant material and growth chamber conditions, two EB isolates showing significant biological control against $P s l$ in the in vitro and in vivo experiments were selected to monitor population density in the cucumber plant root and shoot over a 30-day period from sowing under the same conditions described above.

To monitor the endophytic bacterial population inside the cucumber plants, the two chosen EB isolates were labeled with the antibiotic rifampicin (200 ppm). This procedure was performed to isolate rifampicin-resistant mutants $\left(\right.$ Rif $\left.^{+}\right)$of EB and was previously described by Kloepper (1980). The EB ( Rif $^{+}$) population was monitored in both Psl-inoculated and non-inoculated plants. Plants treated with the pathogen alone on first true leaf stage were considered positive controls. Plants treated only with distilled water were evaluated as negative controls. The EB $\left(\mathrm{Rif}^{+}\right)$isolates were given to agroecosystem by firstly seed bacterization and then soil drench on first true leaf stage 1-2 days before pathogen inoculation. The experiments used to determine the populations of the EB (Rif ${ }^{+}$) mutants and the pathogen were
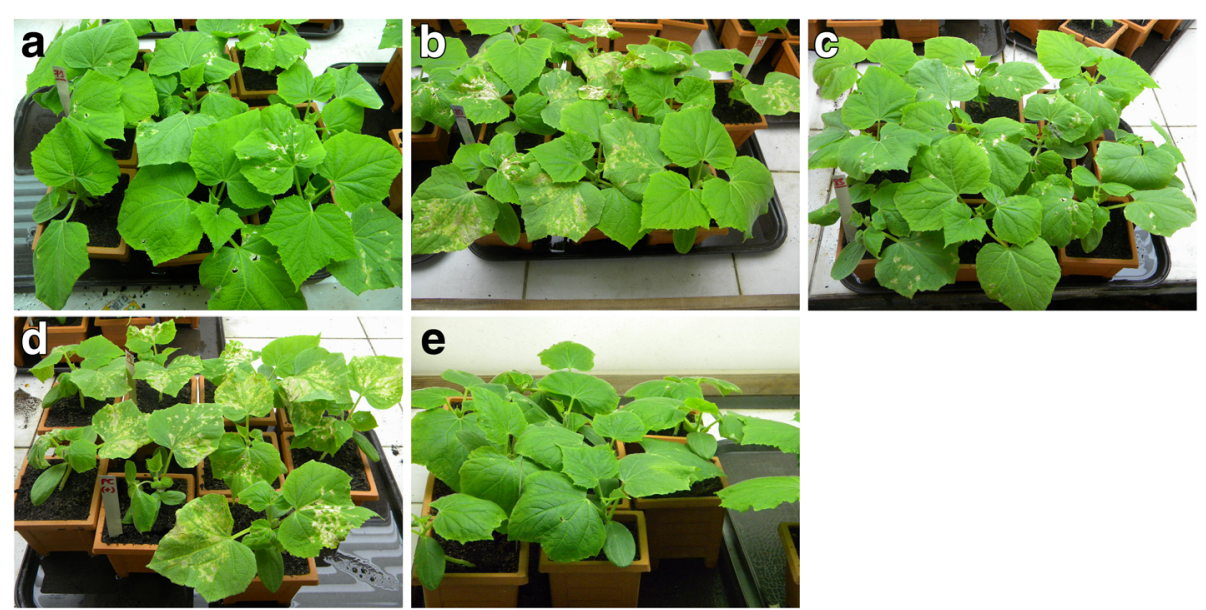

Fig. 1 a The symptom development of Pseudomonas syringae pv. lachrymans on cucumber plants treated with isolate (CA332-73) 7 days after pathogen inoculation. b The symptom development of Pseudomonas syringae pv. lachrymans on cucumber plants treated with isolate (CC361-80) 7 days after pathogen inoculation. c The symptom development of Pseudomonas syringae pv. lachrymans on cucumber plants treated with isolate (CC372-83) 7 days after pathogen inoculation. $\mathbf{d}$ The symptom development of Pseudomonas syringae pv. lachrymans on cucumber plants inoculated with pathogen only 7 days after pathogen inoculation (positive control). e The cucumber plants treated with only sterile distilled water (negative control) 
arranged in a completely randomized block design consisting of three replicates, with one plant per replicate. Disease assessment was conducted as described above. As shown in Table 2, the three samples for each EB (Rif ${ }^{+}$) treatment were taken at different time intervals after seed bacterization.

Treated plant samples [5 g each of roots and shoots (including stem segments, petioles, and leaves) of the whole plant] were surface sterilized with $70 \%$ ethanol for $5 \mathrm{~min}$ followed by $1 \%$ sodium hypochlorite for $1 \mathrm{~min}$ then washed three times in distilled water $(1 \mathrm{~min}$ per rinse). The samples were then ground and processed as described above to determine the microbial populations in them. Root and shoot extracts (typically $100 \mu \mathrm{L}$ for standard $90 \mathrm{~mm} \varnothing$ Petri dish) were serially diluted tenfold and spread on Petri dishes containing KB medium amended with rifampicin (200 ppm). The plates were incubated at $24{ }^{\circ} \mathrm{C}$ for 3 days, then the EB (Rif ${ }^{+}$) colonies were calculated.

To determine pathogen colonization, the plant samples were taken at different time intervals after inoculation, as shown in Table 2 . Plant shoots were gently rinsed in sterile distilled water. Shoot tissues (5 g/plant) were macerated with a manual stomacher in sterile polyethylene bags containing $100 \mathrm{~mL}$ phosphate-buffered saline solution. Macerates were then shaken for approximately $30 \mathrm{~min}$ at $24{ }^{\circ} \mathrm{C}$ on a rotary shaker $(120 \mathrm{rpm})$. Extracts (typically $100 \mu \mathrm{L}$ for standard $90 \mathrm{~mm} \varnothing$ Petri dish) were serially diluted tenfold and plated on modified KBZ medium (Anonymous 2012) known to be selective for Psl. Pathogen colonies were counted after 3 days incubation at $24{ }^{\circ} \mathrm{C}$. The pathogenicity tests conducted on healthy cucumber plants containing bacterial colonies supported Koch's postulates (Agrios 2005).

\section{Endophyte identification by bacterial $16 \mathrm{~S}$ rRNA gene sequencing}

In preparation for DNA extraction, EB isolates CB361-80 and CC372-83 were grown on KB medium for $24-48 \mathrm{~h}$ at

Table 2 Time intervals to monitor population dynamics and colonization of endophytic bacteria $\left(\mathrm{Rif}^{+}\right)$isolates and pathogen inside cucumber root and shoot

\begin{tabular}{|c|c|c|}
\hline \multicolumn{2}{|c|}{ Sampling dates } & \multirow{2}{*}{$\begin{array}{l}\text { Monitoring bacterial isolates } \\
\text { Only EB }\left(\text { Rif }^{+}\right) \text {isolates }\end{array}$} \\
\hline 1 & 30 min after seed bacterization & \\
\hline 2 & $\begin{array}{l}1 \text { day after seed bacterization } \\
\text { and surface disinfection }\end{array}$ & Only EB $\left(\right.$ Rif $\left.^{+}\right)$isolates \\
\hline 3 & First true leaf stage & Only EB $\left(\right.$ Rif $\left.^{+}\right)$isolates \\
\hline 4 & 1 day after Ps/ inoculation & $\begin{array}{l}\text { Pathogenic bacterium and EB } \\
\left(\text { Rif }^{+}\right) \text {isolates }\end{array}$ \\
\hline 5 & 3 days after $P_{s} /$ inoculation & Pathogen and $\mathrm{EB}\left(\mathrm{Rif}^{+}\right)$isolates \\
\hline 6 & 7 days after $P_{s} /$ inoculation & Pathogen and EB $\left(\mathrm{Rif}^{+}\right)$isolates \\
\hline 7 & 14 days after $P_{S} /$ inoculation & Pathogen and EB ( Rif $^{+}$) isolates \\
\hline
\end{tabular}

$24{ }^{\circ} \mathrm{C}$. DNA was extracted from EB suspensions by the boiling lysis method. EB suspensions were prepared in sterile distilled water at an $\mathrm{OD}_{600}$ of 0.1 then centrifuged at $15,000 \times g$ for $10 \mathrm{~min}$. The pellets were resuspended in $40 \mu \mathrm{L}$ ultrapure water, boiled at $100{ }^{\circ} \mathrm{C}$ for $10 \mathrm{~min}$, cooled on ice, centrifuged at $15,000 \times g$ for $10 \mathrm{~s}$, then stored at $20{ }^{\circ} \mathrm{C}$. The DNA extract was used as a template for PCR amplification (Omar et al. 2014). The universal primers 27F (5' AGAGTTTGATCMTGGCTCAG 3') and 1492R (5' TACGGYTACCTTGTTACGACTT $3^{\prime}$ ) were used in the PCR to amplify approximately $1428 \mathrm{bp}$ of $16 \mathrm{~S}$ rDNA. The primers were designed by Lane and associates in 1991 for the 27th and 1492nd positions in the Escherichia coli 16S rRNA gene region and reviewed in Hodkinson and Lutzoni 2009. The final PCR reaction mixture contained 100 ng DNA extract, 10× Taq KCI reaction buffer (Fermentas), $1 \mathrm{mM}$ of each primer, $1.5 \mathrm{mM} \mathrm{MgCl}_{2}$ (Fermentas), $0.2 \mathrm{mM}$ dNTP (Fermentas), and $1 \mathrm{U}$ Taq DNA polymerase (recombinant $5 \mathrm{U} / \mu \mathrm{L}$, Fermentas). The amplification proceeded as follows: for $35 \mathrm{cy}-$ cles, there was an initial denaturation at $95{ }^{\circ} \mathrm{C}$ for $3 \mathrm{~min}$, followed by denaturation at $94{ }^{\circ} \mathrm{C}$ for $1 \mathrm{~min}$, then annealing at $50{ }^{\circ} \mathrm{C}$ for $1 \mathrm{~min}$, then extension at $72{ }^{\circ} \mathrm{C}$ for $2 \mathrm{~min}$, and a final extension at $72{ }^{\circ} \mathrm{C}$ for $5 \mathrm{~min}$ in a thermal cycler (Eppendorf Mastercycler Personal). The PCR products were then subjected to electrophoresis on $1.5 \%$ agarose gel in $0.5 \times$ TAE buffer (50x Tris-acetate-EDTA, Fermentas) with RedSafeT nucleic acid staining solution $(20.000 \times)$ (iNtRON Biotechnology). The gel was run at $80 \mathrm{~V}$ for $90 \mathrm{~min}$. DNA bands were visualized under UV light using a GeneRuler ${ }^{\mathrm{rm}} 1 \mathrm{~kb}$ DNA Ladder (Fermentas).

The amplified products were purified with a QIAquick Gel Extraction Kit (QIAGEN). Sequencing was performed by a Macrogen online sequencing order system (Macrogen, Netherlands). Sequence editing and inspection were done with Sequencher V5.4.5. The DNA sequences of the PCR products were compared with GenBank sequences using BLASTn software (http://blast.ncbi.nlm.nih.gov/). The 16S rRNA sequences of the EB in this study were deposited with accession numbers in the GenBank database.

\section{Statistical analysis}

Endophytic bacterial population data were separately transformed to $\log$ root and shoot CFU/g before averaging. All data were analyzed with Microsoft Excel 2010 and SPSS (IBM SPSS Statistics, version 24.0). The data obtained were subjected to ANOVA (analysis of variance). The population data were transformed to log $(\mathrm{CFU} / \mathrm{g})$. Means were compared using Duncan's $t$ test with a level of significance $P<0.05$, and the SD were calculated. 


\section{Results and discussion}

In vivo biocontrol effects of endophytic bacterial isolates against Pseudomonas syringae pv. lachrymans

According to the average of duplicate experiments under the growth chamber conditions (Table 3), 14 days after pathogen inoculation, approximately $12.5 \%$ of the EB isolates tested (CA332-73, CB361-80, CC372-83) reduced Psl disease severity by $>50 \%$ with respect to that of plants inoculated with pathogen only. In addition to the observations, 7 days after pathogen inoculation, symptom development on plants was suppressed significantly by these isolates (Fig. $1 \mathrm{a}-\mathrm{c}$ ) compared with plants inoculated with pathogen only (Fig. 1d). Statistical analyses of the two experiments indicated that $\mathrm{EB}$ isolates CA332-73, CB361-80, and CC372-83 were the ones to

Table 3 Effects of endophytic bacteria treatments on Pseudomonas syringae pv. lachrymans disease severity in cucumber plants under growth chamber conditions

\begin{tabular}{|c|c|c|}
\hline EB treatments & Average disease severity $(\%)^{a}$ & Efficacy $(\%)^{b}$ \\
\hline CB23-6 & $33.2 \pm 3.78 \mathrm{abcd}^{c}$ & 43.4 \\
\hline CC72-14 & $42.8 \pm 4.25$ bcde & 27.1 \\
\hline CB82-16 & $44.6 \pm 4.30$ cde & 24.0 \\
\hline CB93-19 & $36.0 \pm 2.01$ abcde & 38.7 \\
\hline CB182-37 & $48.1 \pm 5.08$ ef & 18.1 \\
\hline CC252-49 & $37.1 \pm 2.81$ abcde & 36.8 \\
\hline CC26-50 & $43.9 \pm 5.03$ cde & 25.2 \\
\hline CA281-56 & $37.3 \pm 2.86$ abcde & 36.5 \\
\hline CA282-57 & $42.6 \pm 4.70$ bcde & 27.4 \\
\hline CA291-60 & $37.2 \pm 4.36$ abcde & 36.6 \\
\hline CA292-61 & $32.1 \pm 3.80 \mathrm{abc}$ & 45.3 \\
\hline CC293-66 & $36.5 \pm 3.20$ abcde & 37.8 \\
\hline CC30-68 & $43.2 \pm 3.32$ cde & 26.4 \\
\hline CA332-73 & $29.2 \pm 2.81 \mathrm{a}$ & 50.3 \\
\hline CB361-80 & $29.7 \pm 2.54 \mathrm{ab}$ & 49.4 \\
\hline CB362-81 & $42.7 \pm 3.61$ bcde & 27.3 \\
\hline CC372-83 & $29.3 \pm 2.45 a$ & 50.1 \\
\hline CA38-85 & $37.5 \pm 4.15$ abcde & 36.1 \\
\hline CB382-87 & $39.9 \pm 3.00$ abcde & 32.0 \\
\hline CA391-88 & $36.2 \pm 1.95$ abcde & 38.3 \\
\hline CC393-93 & $48.0 \pm 6.54$ ef & 18.2 \\
\hline CB401-95 & $46.1 \pm 5.65 \mathrm{de}$ & 21.5 \\
\hline CA411-99 & $37.6 \pm 2.13$ abcde & 35.9 \\
\hline CC44-112 & $31.4 \pm 3.10 a b c$ & 46.5 \\
\hline Control + & $58.7 \pm 4.15 f$ & 0.00 \\
\hline
\end{tabular}

${ }^{a}$ Average of ten plants per replicate. The results are an average of the two seasons of 2012 and 2013

${ }^{\mathrm{b}}$ Percentage reduction in disease severity compared to plants treated with pathogen alone

"Means within columns sharing a letter in common are not significantly different $(P<0.05$; Duncan test). The standard error of each set is displayed be selected for further studies such as plant tissue colonization and molecular identification. However, the vigor index value of cucumber plants treated with isolate CA332-73 was lower than non-treated negative control (Table 1). The vigor index is an important parameter to germination of seed (Marcos-filho 2015). Some studies showed that the bacteria synthesized the plant growth regulators, auxin, gibberellin, cytokinin, and abscisic acid (Tuomi and Rosenqvist 1995; Karadeniz et al. 2006; Babalola et al. 2007; Babalola 2010). Although some phytohormones secreted by bacteria showed beneficial effects on plant growth, the high-level production of ethylene and abscisic acid by some bacteria could inhibit seed germination and also lead to abnormal root growth, which could seriously impede plant growth and development (Schopfer and Plachy 1985). One of the possible reasons of the negative effect on vigor index by isolate CA332-73 could be caused by production of some metabolites like ethylene and abscisic acid. For that reason, isolate CA332-73 was not used for further studies.

\section{Monitoring the colonization of endophytic bacteria and Pseudomonas syringae pv. lachrymans in cucumber plants} Rifampicin-resistant mutants (Rif ${ }^{+}$) of EB isolates CB361-80 and CC372-83 were selected to monitor EB colonization rates inside the cucumber plants. The populations of these bacterial isolates on surface-sterilized seeds were $3 \times 10^{6}-7.1 \times 10^{7} \mathrm{CFU} / \mathrm{g} 1$ day after bacterization. Endophytic colonization continued in cucumber plant tissues at the first true leaf stage. EB populations there ranged from $1.4 \times 10^{4}$ to $1.7 \times 10^{6} \mathrm{CFU} / \mathrm{g}$ shoot. In the absence of Psl, EB populations in the shoots remained between $3.8 \times 10^{4}$ and $8 \times 10^{4} \mathrm{CFU} / \mathrm{g}$. In plants exposed to $P s l$, EB population levels were from $1.9 \times 10^{5}$ to $2.2 \times 10^{5} \mathrm{CFU} / \mathrm{g} 45$ days after seed bacterization.

The population level of EB isolates CB361-80 and CC372-83 in the root tissues were between $1.6 \times 10^{5}$ and $6.3 \times 10^{5} \mathrm{CFU} / \mathrm{g}$ at the first true leaf stage. In the absence of $P s l$, EB populations ranged from $2 \times 10^{4}$ to $7.5 \times 10^{4} \mathrm{CFU} / \mathrm{g}$. EB populations in roots inoculated with Psl were between $5.8 \times 10^{4}$ and $2.7 \times 10^{4} \mathrm{CFU} / \mathrm{g} 45$ days after seed bacterization.

EB isolates CB361-80 and CC372-83 successfully colonized cucumber shoot and root (Fig. 2a, b). The colonizations of EB isolates CB361-80 and CC372-83 were not significantly affected by $P s l$ inoculation during the entire sampling period.

Psl population levels were also monitored in cucumber plants treated and not treated with EB isolates. Psl levels in cucumber plants receiving the pathogen alone (no EB) reached from $4.5 \times 10^{4}$ to $9.5 \times 10^{8} \mathrm{CFU} / \mathrm{g} 14$ days after inoculation.

Psl colonization rates in cucumber plants treated with EB isolates CC372-83 and CB361-80 were between $3.3 \times 10^{3}$ 

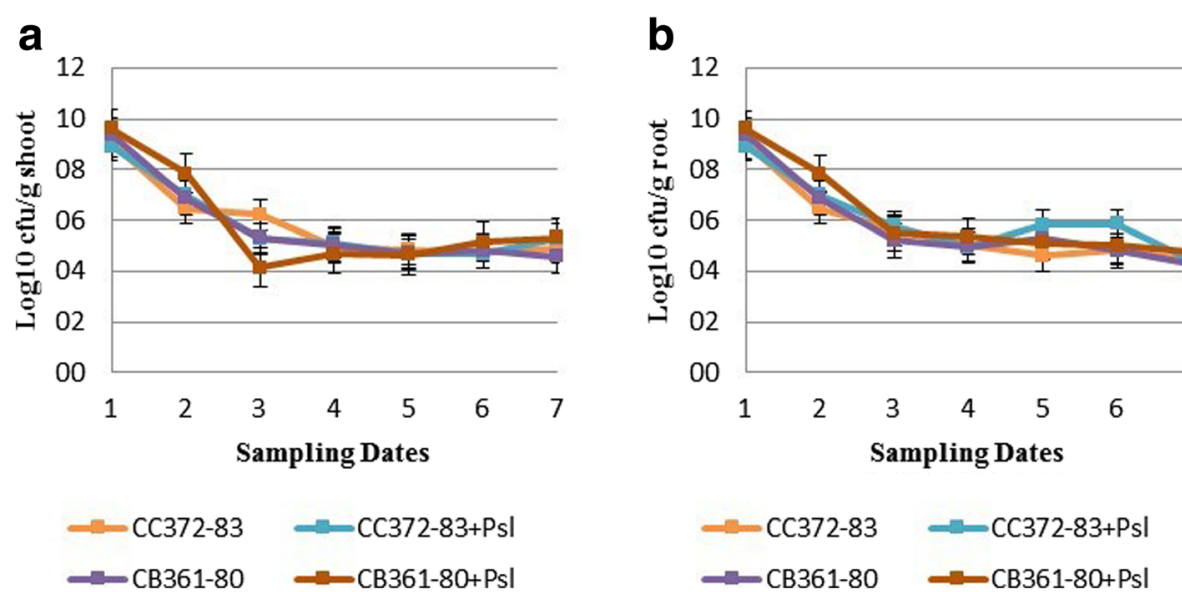

Fig. 2 a Endophytic colonization of isolates CB361-80 and CC372-83 in cucumber plant tissues (shoot) (either not inoculated or inoculated with Pseudomonas syringae pv. lachrymans) at different sampling dates according to (Table 2). The population data for graphs were transformed to log (CFU/g). b Endophytic colonization of isolates CB361-80 and CC372-83 in cucumber plant tissues (root) (either not inoculated or inoculated with Pseudomonas syringae pv. lachnymans) at different sampling dates according to (Table 2). The population data for graphs were transformed to log (CFU/g)

and $4.2 \times 10^{4} \mathrm{CFU} / \mathrm{g}$, respectively, 1 day after Psl inoculation. $P s l$ levels were between $3 \times 10^{7}$ and $2.6 \times 10^{8} \mathrm{CFU} / \mathrm{g}$, respectively, 14 days after Psl inoculation (Fig. 3).

Psl populations in cucumber plants treated with EB isolate CC372-83 were lower than those in cucumber plants treated with EB isolate CB361-80, according to the results of monitoring 14 days after Psl inoculation. These data were confirmed by statistical analysis.

\section{Identification of promising endophytes}

EB isolates CB361-80 and CC372-83 were the most promising bacteria for the biological control of Psl. They were identified using 27F/1492R universal 16S rRNA primers. The products of the 1428-bp sequence were obtained by PCR using DNA from EB isolates CB361-80 and CC372-83. Partial 16S rRNA gene sequencing and their analysis via BLASTn in NCBI database revealed that EB isolates (CB361-80) and (CC372-83) have sequences that are highly similar (99\%) to those of Ochrobactrum pseudintermedium and Pantoea agglomerans, respectively. Therefore, these EB isolates were identified as Ochrobactrum sp. and Pantoea sp. due to the complex taxonomy of genus Ochrobactrum and Pantoea. The 16S rRNA sequences of the EB determined

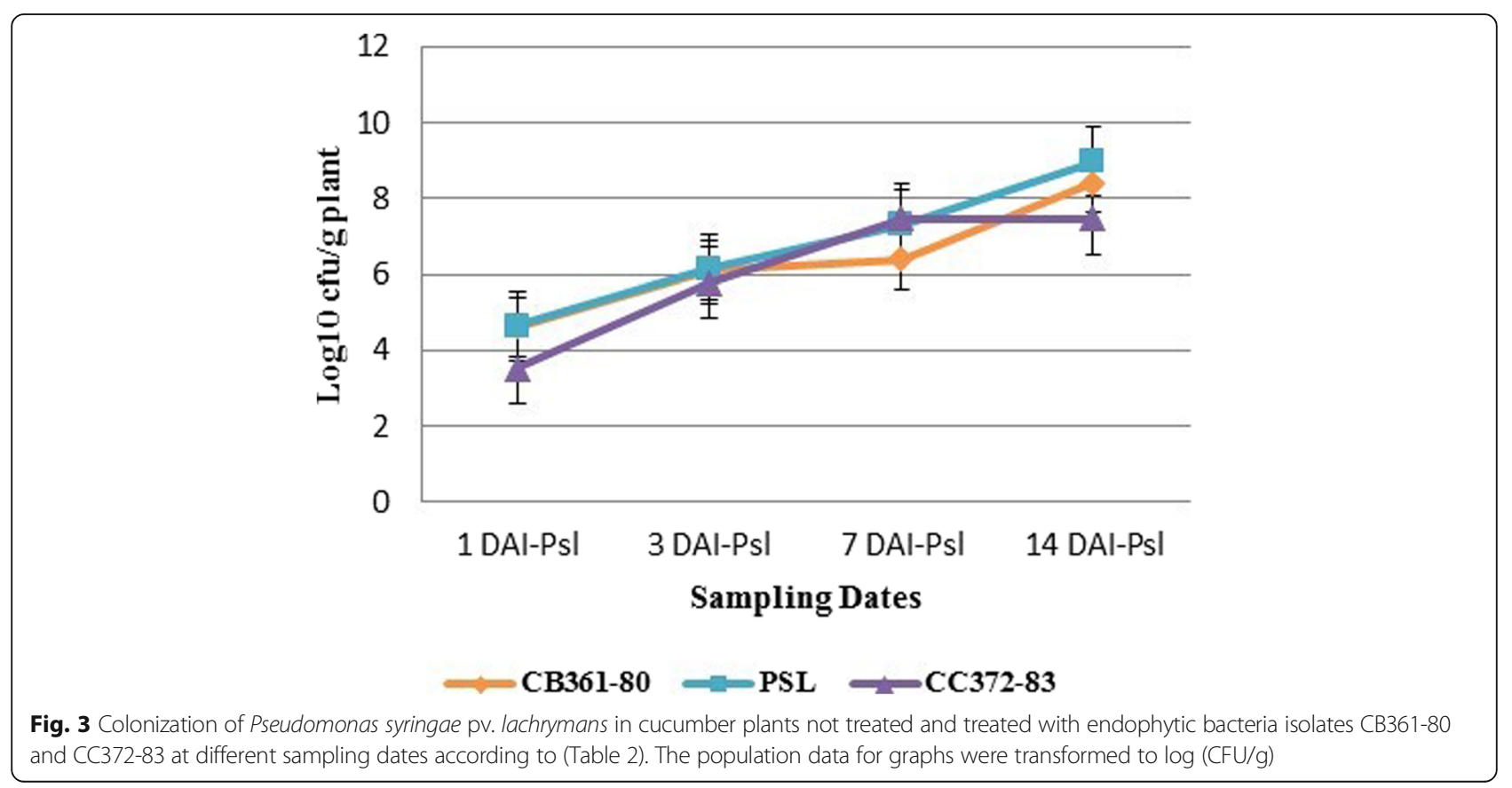


in this study have been deposited in the GenBank database under accession numbers KX589254-KX589255.

Endophytic bacteria have been identified in several different genera that include both non-pathogens and plant/human pathogens (Rosenblueth and MartínezRomero 2006; Melnick et al. 2008; Assumpção et al. 2009). According to sequence analysis of the $16 \mathrm{~S}$ rRNA of the EB isolates, endophytes of CB361-80 and CC37283 isolated from cucumber plants were identified as Ochrobactrum sp. and Pantoea sp., respectively. The previous studies reported that 16S rRNA gene sequencebased bacterial identification can better identify poorly described, rarely isolated, or phenotypically aberrant strains. It was also considered as a precise method of bacterial identification because it can provide bacterium species-specific signature (Clarridge 2004; Preveena and Bhore 2013). However, because of the complex taxonomy of genus Ochrobactrum and Pantoea, it is necessary to perform other identification tests prior to confirming their identity, such as the use of the approach of Teyssier et al. (2007). According to this study, $16 \mathrm{~S}$ rRNA gene sequence-based identification method of bacteria could be used for rapid identification, but it is necessary to perform other special identification tests prior to confirming bacterial identity. This method is not enough alone to approve to the identity of bacterial species in some genera. In the next phase of this study, the further diagnostic tests i.e. morphological, physiological, and biochemical tests for these bacterial isolates will be perform to confirm their identity.

Promising experimental data have shown that the application of antagonistic bacteria could serve as an alternative approach to the biological control of plant diseases (Poon et al. 1977; Chen et al. 1995; Sturz and Matheson 1996). It has been reported that Pseudomonas putida 89B-27 and Serratia marcescens 90-166 could reduce angular leaf spot disease severity and incidence in cucumber via rhizobacteria-mediated induced systemic resistance (ISR) (Liu et al. 1995a). The ability of EB to suppress disease in cucumber depends mainly on its antagonism against the pathogen $(P s l)$ colonization in the internal tissues and on its production of various inhibitory substances and bacteriocins. It is possible that several mechanisms such as antibacterial compounds, siderophore production, nutrient competition, niche exclusion, and induction of systemic resistance (ISR) play a role in the biological control demonstrated by endophytes (Cook and Baker 1983). The results of our previous study indicated that while isolates CB361-80 and CC372-83 produced IAA and siderophores and solubilize phosphate, it did not produce effective antibacterial compounds. These properties have been directly or indirectly correlated with their biocontrol activity of the two endophytes (Ozaktan et al. 2015).
Some of these mechanisms play a role in the biological control of Psl demonstrated by CB361-80 and CC372-83 isolates. Our results suggest that ISR or nutrient competition may be important factors of biocontrol of Psl by these endophyte isolates.

Results demonstrated that both EB strains colonized internal cucumber host tissues. This study also showed that CB361-80 and CC372-83 could form and sustain populations in the internal root and shoot tissues of both Psl-infected and uninfected cucumber plants. The EB population density in surface-sterilized cucumber seeds was in the range of $3 \times 10^{6}-7.1 \times$ $10^{7} \mathrm{CFU} / \mathrm{g}$, so EB successfully penetrated the cucumber seeds. EB populations in cucumber shoots and roots changed over time, but on average, they colonized the plant organs at the rate of $10^{4}-10^{5} \mathrm{CFU} / \mathrm{g}$ under growth chamber conditions over 30 days from sowing. In this study, the large standard errors are indicative of variation among replications within some treatments of the colonization studies presented here in (Figs. 2a, b and 3). The lower populations were included as zero in the data set. Chen et al. 1995 suggested that endophytic populations, particularly at lower levels, were probably underestimated. Our results corroborate those of previous research on EB colonization rates on sugarcane (Dong et al. 1994), alfalfa (Gagné et al. 1987), and cotton (Misaghi and Donndelinger 1990; Mclnroy and Kloepper 1995). Previous studies suggested that EB population densities vary not only among plant species (Quadt-Hallmann and Kloepper 1996) but also in different plant organs (highest in roots and lowest in shoots (Mclnroy and Kloepper 1995). Nevertheless, our data on CB361-80 and CC372-83 population density did not significantly differ between cucumber root and shoot tissues. In a previous study, it was reported that Pantoea sp. and Ochrobactrum sp. effectively colonized the internal rice root tissues. Nevertheless, Pantoea sp. was more effective at colonizing rice tissues than Ochrobactrum sp. (Assumpção et al. 2009). These studies showed that the EB P. agglomerans LRC 8311 reduced bacterial wilt disease severity in bean caused by Curtobacterium flaccumfaciens pv. flaccumfaciens and very effectively colonized bean seedlings (Hsieh et al. 2005). Ochrobactrum sp. colonized internal soybean tissues and was antagonistic to three phytopathogenic fungi: Fusarium oxysporum (soybean, cotton, and bean), Fusarium semitectum, and Cercospora kikuchii (both soybean) according to Assumpção et al. (2009). The ability of bacterial endophytes to colonize internal host plant tissues may in part account for their effectiveness in controlling the systemic invasion of angular leaf spot. Competition between $P s l$ and endophytic isolate CC372-83 tends to reduce the pathogen 
population in their common habitat. This fact could be strong evidence for the biocontrol ability of the endophyte CC372-83 against Psl.

Both EB isolates decreased disease severity caused by Psl on cucumber plants for the result of in vivo tests. Nevertheless, while CC372-83 had decreased Psl population density to a level tenfold less than that in plants treated with $P s l$ alone, CB361-80 has not decreased Psl population density. In addition, the population densities of CB361-80 and CC372-83 inside the cucumber tissues have not decreased following $P s l$ inoculation. (Pieterse et al. 1998) reported that disease severity suppression without a concomitant decrease in pathogen population density could be explained by the presence of rhizobacteria inducing systemic resistance (ISR) in the host plants. Bacterial endophytes and their roles in ISR have been reviewed by Kloepper and Ryu 2006. This study suggests the possibility that enhanced host defenses will be responsible for the reduction of symptom severity of $P s l$ because of other mechanisms, such as antibacterial compounds, nutrition competition, and niche exclusion which are less likely according to in vitro test results.

EB inoculation should promote the establishment of the microorganism in the soil and on the plant and support host penetration and colonization. Seed inoculation is an efficient and convenient way of introducing $\mathrm{EB}$ to plants (Bejarano et al. 2014). Our results showed that EB applied to the pathosystem via seed bacterization and soil drenching effectively inhibited $P s l$ disease symptom development in cucumber. When the endophyte population began to decrease inside the plants, the soil drenching treatment with endophytes is applied to the plants. Following that, the populations of endophytes in plant shoot and root maintained not to change too much until the end of the experiments. This situation of endophyte populations could be sourced from shortly monitoring time (only 14 days) after treatment.

\section{Conclusions}

The aforementioned EB isolates may be candidates for the biological control of Psl. Nevertheless, there remains much to be investigated in order to gain a better understanding of all the interactions involved between pathogen, host plant, and EB. The EB biocontrol mechanism against Psl must be proven through further studies, including molecular gene expression experiments. In the further phase of this study, the focus will be the detection of the genes involved in inducing plant resistance.

\section{Acknowledgements}

The authors also wish to thanks Professor Charles MANCEAU for providing the strain of Pseudomonas syringae pv. lachrymans CFPB 2262.

\section{Funding}

This study was supported by national grants from the Scientific and Technological Research Council of Turkey (TUBITAK-COST 111 O 505), Ege
University Science-Technology Research and Application Center (EBILTEM), and the Academical Staff Training Program (OYP) supported by Higher Education Council (YOK).

\section{Authors' contributions}

MA carried out the growth chamber and colonization studies, participated in the sequence alignment and drafted the manuscript. $\mathrm{HO}$ participated in the design of the study and performed the statistical analysis. $\mathrm{HO}$ conceived of the study and participated in its design and coordination. Both authors read and approved the final manuscript.

\section{Competing interests}

The authors declare that they have no competing interests.

\section{Publisher's Note}

Springer Nature remains neutral with regard to jurisdictional claims in published maps and institutional affiliations.

Received: 28 June 2017 Accepted: 6 December 2017

Published online: 15 February 2018

\section{References}

Agrios G (2005) Plant pathology, 5th edn. Academic Press, New York, 922 pp

Anonymous, 2012. K5129 KBZ medium. In: Duchefa Biochem. B.V. http://brochure. duchefa-biochemie.com/Phytopathology_Media/docs/Phytopathology_ Media.pdf. Accessed 2 Aug 2016

Anonymous, 2013. Cucumber and gherkins production of top 5 producers. http://faostat3.fao.org/browse/Q/QC/E. Accessed 10 Aug 2016

Assumpção LC, Lacava PT, Dias ACF, Azevedo JL, Menten JOM (2009) Diversidade e potencial biotecnológico da comunidade bacteriana endofítica de sementes de soja. Pesq Agropec Bras 44:503-510

Azevedo JL, Maccheroni JW, Pereira JO, Araújo WL (2000) Endophytic microorganisms: a review on insect control and recent advances on tropical plants. Electron J Biotechnol 3:1-4

Babalola OO (2010) Ethylene quantification in three rhizobacterial isolates from Striga hermonthica-infested maize and sorghum. Egypt J Biol 12:1-5

Babalola OO, Sanni Al, Odhiambo GD, Torto B (2007) Plant growth-promoting rhizobacteria do not pose any deleterious effect on cowpea and detectable amounts of ethylene are produced. World J Microbiol Biotechnol 23(6):747-752

Bandara WMMS, Seneviratne G, Kulasooriya SA (2006) Interactions among endophytic bacteria and fungi: effects and potentials. J Biosci 31:645-650

Bejarano A, Mitter B, Preininger C (2014) Development of bacteria formulations for seed coating. In: Jakobs-Schönwandt D, Döring M, Patel A (eds) Application techniques of endophytes, p 89

Bhandari G (2014) An overview of agrochemicals and their effects on environment in Nepal. Appl Ecol Environ Sci 2(2):66-73

Bhat NA, Bhat KA, Zargar MY, Teli MA, Nazir M, Zargar SM (2010) Current status of angular leaf spot ( Pseudomonas syringae pv. lachrymans ) of cucumber. Int J Curr Res 8:1-11

Bhat NA, Masoodi SD, Ahmad M, Zargar M (2007) Occurrence and severity of angular leaf spot of cucumber in Kashmir. Ann Plant Prot Sci 15:410-413

Bills GF, Polishoo JD (1991) Microfungi from Carpinus caroliniana. Can J Bot 69: 1477-1482

Chen C, Bauske EM, Musson G, Rodriguezkabana R, Kloepper JW (1995) Biological control of Fusarium wilt on cotton by use of endophytic bacteria. Biol Control 5:83-91

Clarridge JE (2004) Impact of 165 rRNA gene sequence analysis for identification of bacteria on clinical microbiology and infectious diseases. Clin Microbiol Rev 17:840-862

Compant, S., B. Duffy, J. Nowak, C. Cle, and E. A. Barka 2005. Use of plant growthpromoting bacteria for biocontrol of plant diseases: principles, mechanisms of action, and future prospects, Minireview. Appl Environ Microbiol, 71:4951-4959

Cook RJ, Baker KF (1983) The nature and practice of biological control of plant pathogens. Am. Phytopathol. Soc, St. Paul, p 539

Dong Z, Canny MJ, McCully ME, Roboredo MR, Cabadilla CF, Ortega ERR (1994) A nitrogen-fixing endophyte of sugarcane stems (a new role for the apoplast). Plant Physiol 105:1139-1147

Gagné S, Richard C, Rousseau H, Antoun H (1987) Xylem-residing bacteria in alfalfa roots. Can J Microbiol 33.996-1000

Gerhardson B (2002) Biological substitutes for pesticides. Trends Biotechnol 20:338-343 
Hodkinson BP, Lutzoni F (2009) A microbiotic survey of lichen-associated bacteria reveals a new lineage from the Rhizobiales. Symbiosis 49:163-180

Hsieh TF, Huang HC, Erickson RS (2005) Biological control of bacterial wilt of bean using a bacterial endophyte, Pantoea agglomerans. J Phytopathol 153:608-614 Johri BN (2006) Endophytes to the rescue of plants! Curr Sci 90:1315-1316

Karadeniz A, Topcuoğlu ŞF, Inan S (2006) Auxin, gibberellin, cytokinin and abscisic acid production in some bacteria. World J Microbiol Biotechnol 22(10):1061-1064

Khlaif, $\mathrm{H}$ and H. Abu Blan 1990. Control of angular leaf spot (Pseudomonas syringae pv. lachrymans) (Smith and Bryan) of cucumber in Jordan. http://agris.fao.org/ agris-search/search.do?recordID=JO19920033752. Accessed 15 Sep 2017

Klement Z, Mavridis A, Rudolph K, Vidaver A (1990) Inoculation of plant tissues. In: Klement Z, Rudolph K, Sands DC (eds) Methods in phytobacteriology. Akademiai Kiado, Budapest, pp 94-124

Kloepper JW (1980) Effects of rhizosphere colonization by plant growthpromoting rhizobacteria on potato plant development and yield. Phytopathology 70:1078-1082

Kloepper JW, Ryu C (2006) Bacterial endophytes as elicitors of induced systemic resistance. Microb Root Endophytes 9:33-52

Liu L, Kloepper JW, Tuzun S (1995a) Induction of systemic resistance in cucumber against bacterial angular leaf spot by plant growth-promoting rhizobacteria. Biol Control 85:843-847

Liu L, Kloepper JW, Tuzun S (1995b) Induction of systemic resistance in cucumber against Fusarium wilt by plant growth-promoting rhizobacteria. Phytopathology 85:695-698

Lwin M, Ranamukhaarachchi SL (2006) Development of biological control of Ralstonia solanacearum through antagonistic microbial populations. Int J Agric Biol 8:657-660

Marcos-filho J (2015) Seed vigor testing: an overview of the past, present and future perspective. Sci Agric 72:363-374

Mclnroy JA, Kloepper JW (1995) Population dynamics of endophytic bacteria in field-grown sweet corn and cotton. Can J Microbiol 41:895-901

Melnick RL, Zidack NK, Bailey BA, Maximovad SN, Guiltinan M, Backman PA (2008) Bacterial endophytes: Bacillus spp. from annual crops as potential biological control agents of black pod rot of cacao. Biol Control 46:46-56

Michelson LF, Lachman WH, Allen DD (1958) The use of the "weighted-rankit" method in variety trials. Proc American Soc Horticult Science 71:334-338

Miguel PSB, Delvaux JC, de Monteiro LCPOMNV, Freitas FS, Costa MD, Tótola MR, Moraes CA (2013) Diversity of endophytic bacteria in the fruits of Coffea canephora. African J. Microbiol. Res. 7:586-594

Misaghi IJ, Donndelinger CR (1990) Endophytic bacteria in symptom-free cotton plants. Phytopathology 80:808-811

Omar BA, Atif HA, Mogahid ME (2014) Comparison of three DNA extraction methods for polymerase chain reaction (PCR) analysis of bacterial genomic DNA. African J Microbiol Res 8:598-602

Ozaktan H, Bora T (1994) Antagonistik bakterilerin hıyar köşeli leke (Pseudomonas syringae pv. lachrymans) hastalığının biyolojik savaşımında kullanılma olanakları üzerinde araştırmalar. In: Türkiye 3. Biyolojik Mücadele Kongresi, İzmir, pp 221-229

Ozaktan H, Çakır B, Gül A, Yolageldi L, Akköprü A, Fakhraei D, Akbaba M (2015) Isolation and evaluation of endophytic bacteria against Fusarium oxysporum f. sp. cucumerinum infecting cucumber plants. Austin J Plant Biol 1:1-6

Ozaktan H, Gül A, Çakır B, Yolageldi L, Akköprü A, Fakhraei D, Akbaba M (2013) Isolation optimization of bacterial endophytes from cucumber plants and evaluation of their effects on growth promotion and biocontrol. In: Schneider C, Leifert CFF (eds) Endophytes for plant protection: the state of the art. Deutsche Phytomedizinische Gesellschaft, Braunschweig, pp 262-268

Pieterse CMJ, van Wees SCM, Van Pelt JA, Knoester M, Laan R, Gerrits H, Weisbeek PJ, Van Loon LC (1998) A novel signaling pathway controlling induced systemic resistance in Arabidopsis. Plant Cell 10:1571-1580

Poon ES, Huang TC, Kuo TT (1977) Possible mechanism of symptom inhibition of bacterial blight of rice by endophytic bacterium isolated. Bot Bull Acad Sin 18:61-70

Preveena J, Bhore SJ (2013) Identification of bacterial endophytes associated with traditional medicinal plant Tridax procumbens Linn. Anc Sci Life 32:173-177

Quadt-Hallmann A, Kloepper JW (1996) Immunological detection and localization of the cotton endophyte Enterobacter asburiae JM22 in different plant species. Can J Microbiol 42:1144-1154

Raupach GS, Kloepper JW (2000) Biocontrol of cucumber diseases in the field by plant growth-promoting rhizobacteria with and without methyl bromide fumigation. Plant Dis 84:1073-1075
Rosenblueth M, Martínez-Romero E (2006) Bacterial endophytes and their interactions with hosts. Mol Plant-Microbe Interact 19:827-837

Ruby JE, Raghunath MT (2011) A review: bacterial endophytes and their bioprospecting. J Pharm Res 4:795-799

Schaad NW, Jones JB, Chun W (2001) Laboratory guide for identification of plant pathogenic bacteria, 3rd edn, St Paul, p 373

Schopfer P, Plachy C (1985) Control of seed germination by abscisic acid: III. Effect on embryo growth potential (minimum turgor pressure) and growth coefficient (cell wall extensibility) in Brassica napus L. Plant Physiol 77(3):676-686

Serçe S, Görgülü Ö (2009) Yapay Bir Veri Seti Ile Tartılı Derecelendirme Yönteminin Yeniden Değerlendirilmesi. Alatarım 8:43-50

Shila SJ, Islam MR, Ahmed NN, Dastogeer KMG, Meah MB (2013) Detection of Pseudomonas syringae pv. lachrymans associated with the seeds of cucurbits. Univers J Agric Res 1:1-8

Smith EF, Bryan MK (1915) Angular leaf-spot of cucumbers. J Agric Res 5:465-476

Strobel G, Daisy B (2003) Bioprospecting for microbial endophytes and their natural products. Microbiol Mol Biol Rev 67:491-502

Sturz AV, Matheson BG (1996) Populations of endophytic bacteria which influence host-resistance to Erwinia-induced bacterial soft rot in potato tubers. Plant Soil 184:265-271

Teyssier C, Marchandin H, Jean-Pierre H, Masnou A, Dusart G, Jumas-Bilak E (2007) Ochrobactrum pseudintermedium sp. nov., a novel member of the family Brucellaceae, isolated from human clinical samples. Int I Syst Evol Microbiol 57:1007-1013

Thomas P, Upreti R (2014) Testing of bacterial endophytes from non-host sources as potential antagonistic agents against tomato wilt pathogen Ralstonia solanacearum. Adv Microbiol 4(10):656-666

Tuomi T, Rosenqvist H (1995) Detection of abscisic, gibberellic and indole-3acetic acid from plants and microbes. Plant Physiol Biochemist 33(6):725-734

Wei G, Kloepper JW, Tuzun S (1996) Induced systemic resistance to cucumber diseases and increased plant growth by plant growth-promoting rhizobacteria under field conditions. Biol Control 86(2):221-224

Zhang W, Han DY, Dick WA, Davis KR, Hoitink HAJ (1998) Compost and compost water extract-induced systemic acquired resistance in cucumber and Arabidopsis. Phytopathology 88:450-455

\section{Submit your manuscript to a SpringerOpen ${ }^{\circ}$ journal and benefit from:}

- Convenient online submission

- Rigorous peer review

- Open access: articles freely available online

- High visibility within the field

- Retaining the copyright to your article

Submit your next manuscript at $>$ springeropen.com 